\title{
Biochemical Studies on L-Ascorbic Acid in Aquatic Animals-VIII Purification and Properties of Dehydro-L-ascorbic Acid Reductase from Carp Hepatopancreas
}

\author{
Yoshikazu Yamamoto," Mamoru SAto,* and Shizunori IKEDA*
}

(Received June 24, 1976)

\begin{abstract}
DAsA-reductase (EC 1.8.5.1) was purified from carp hepatopancreas by ammonium sulfate fractionation, Sephadex G-75 gel filtration and DEAE-Sephadex A-50 column chromatography, obtaining enzyme material enriched about 100 -fold in specific activity with a $23 \%$ yield.

Some properties of the purified enzyme were studied with the following results. Without bovine serum albumin, the enzyme was relatively unstable. Optimal pH and temperature for the enzyme reaction were near 6.7 and $30^{\circ} \mathrm{C}$, respectively. $\mathrm{Co}^{2+}, \mathrm{Zn}^{2+}$, $\mathrm{Hg}^{+}$and $\mathrm{Fe}^{3+}$ strongly inhibited the enzyme activity, while $\mathrm{Cu}^{2+}, \mathrm{Mg}^{2+}$, and $\mathrm{Mn}^{2+}$ had no effect. The enzyme activity was only slightly affected if at all by EDTA, $o$-phenanthrolic acid, sodium azide, sodium arsenate and nucleotides, but was inhibited by sodium cyanide and $\mathrm{CO}$ gas. The $\mathrm{Km}$ value was $5.7 \times 10^{-4} \mathrm{M}$ for DAsA and $1.5 \times 10^{-3} \mathrm{M}$ for GSH. The enzyme was specific for GSH as a bydrogen donor and less specific for DAsA as a hydrogen acceptor. Product inhibition was observed with excess GSSG but not with AsA.
\end{abstract}

In the previous paper ${ }^{1}$, the existence of Dehydro-L-ascorbic acid (DAsA)-reductase (EC 1.8.5.1) which catalyzes the transfer of hydrogen from reduced glutathione (GSH) to DAsA was shown in fishes. In spite of the accumulating knowledge of the enzyme in plant tissues ${ }^{2-7)}$, there are hardly any studies on the purification and properties of the enzyme in animal tissues except for the paper reported by HuGHes ${ }^{8)}$.

In the present paper, a method for the isolation and purification of DAsA-reductase from carp hepatopancreas and some properties of the purified enzyme are described.

\section{Materials and Methods}

Sample Culture carp, Cyprinus carpio, were obtained from commercial suppliers. All were living fish weighing about $400 \mathrm{~g}$.

Materials Hemoglobin was prepared from carp as follows. The blood of carp was obtained by cutting off the posterior portion of the body. In order to prevent coagulation, sodium heparinate was used. Hemolysate of erythrocytes was collected from the blood by centrifugating at $1,000 \times g$ for $15 \mathrm{~min}$, washing the cells 3 times with cold $0.9 \% \mathrm{NaCl}$, and finally hemolyzing with equal volume of water. The hemolysate was stirred vigorously with a third volume of ether for $10 \mathrm{~min}$ at a low temperature, and it was centrifuged at $10,000 \times g$ for $30 \mathrm{~min}$ to remove the stroma and ether. The hemoglobin layer was collected

\footnotetext{
* Dept. Fish., Fac. Agr., Kyoto Univ., Kyoto, Japan（山本義和・佐藤 守・池田静徳：京都大学㩔学部)。
} 
with a syringe and dialyzed overnight at $5^{\circ} \mathrm{C}$ against distilled water. The other reagents were obtained from commercial sources.

Assay of enzyme activity Measurement of DAsA-reductase activity was essentially the same as described in the previous paper ${ }^{1)}$. The reaction mixture containing 22.8 $\mu$ moles of GSH, $11.4 \mu$ moles of DAsA, $600 \mu$ moles of phosphate buffer, $\mathrm{pH} 6.3$, and enzyme solution in a total volume of $6 \mathrm{ml}$, was incubated at $30^{\circ} \mathrm{C}$ by bubbling nitrogen gas through the mixture. The reaction was stopped by the addition of $2 \mathrm{~m} l$ of $20 \%$ $\mathrm{HPO}_{3}$. After filtration through Toyo No. 5c paper, the amount of L-ascorbic acid (AsA) produced from DAsA was then determined by the 2,6-dichlorophenolindophenol method. Enzyme activity was expressed as $\mu$ moles of AsA formed enzymatically from DAsA per $10 \mathrm{~min}$. When the effect of excess AsA on the enzyme reaction was studied, decrease of GSH was determined according to the method of GRUNERT ${ }^{9)}$ as an indication of the activity. HEPES buffer was used in studying the effect of metal ions on the activity in order to prevent their chelation.

\section{Results and Discussion}

\section{Purification of the enzyme}

1. Pretreatment Carp hepatopancreas was homogenized with 3 volumes of cold $0.9 \% \mathrm{NaCl}$ in a Potter-Elvehjem homogenizer. The homogenate was centrifuged at $28,000 \times g$ for $30 \mathrm{~min}$.

2. Ammonium sulfate fractionation The supernatant thus obtained was then fractionated with ammonium sulfate and the precipitates formed between 60 and $80 \%$ saturation were collected. The precipitates were dissolved in a small volume of $0.02 \mathrm{M}$ sodium phosphate buffer, $\mathrm{pH} 7.0$, and the insoluble matter was removed by centrifugation.

3. Sephadex G-75 gel filtration The supernatant was passed through a Sephadex

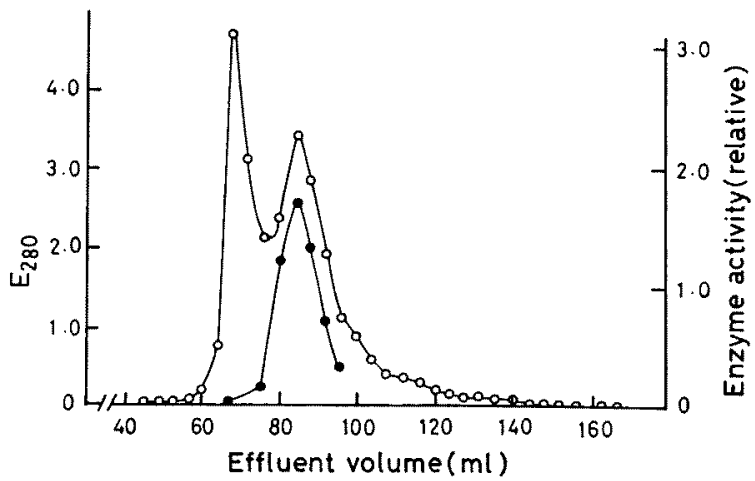

Fig. 1. Sephadex G-75 gel filtration of the $\left(\mathrm{NH}_{4}\right)_{2} \mathrm{SO}_{4}$ fraction of $0.9 \% \mathrm{NaCl}$ extract of carp hepatopancreas. Column size: $2.5 \times 40 \mathrm{~cm}$, flow rate: $15 \mathrm{ml} / \mathrm{hr}$, solvent: $0.02 \mathrm{M}$ sodium phosphate buffer, pH 7.0. - $-\bigcirc-\mathrm{O}^{-} \mathrm{E}_{280},-\bullet-\bullet-$ : Enzyme activity. 
G-75 column $(2.5 \times 40 \mathrm{~cm})$ which had been previously equilibrated with the above phosphate buffer and eluted with the same buffer. A typical elution profile is shown in Fig. 1. Roughly, two peaks absorbing at $280 \mathrm{~nm}$ appeared and the enzymatically active protein was found in the second peak.

The enzyme preparation, partially purified by Sephadex G-75 gel filtration, assumed the characteristic red brown appearance of iron porphrin enzymes. As shown in Fig. 2,

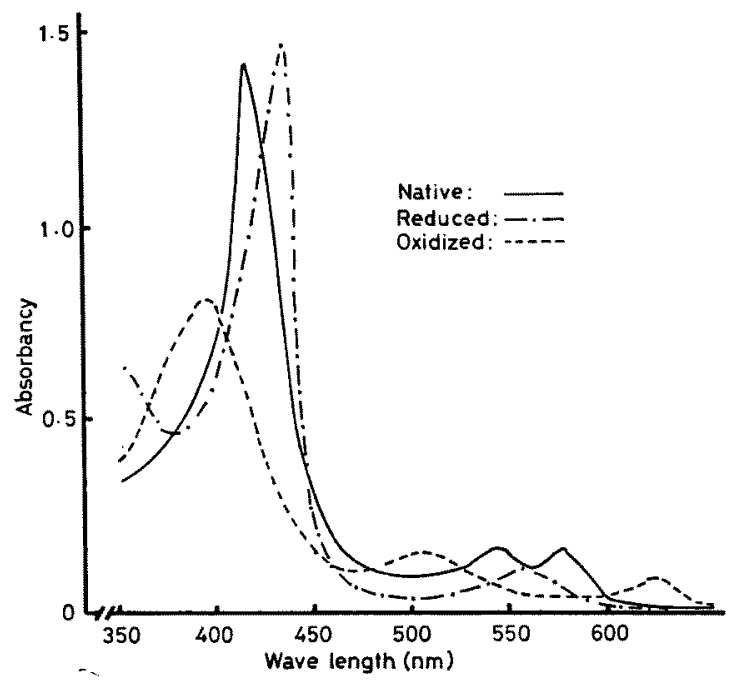

Fig. 2. Absorption spectra of the enzyme partially purified with Sephadex $G-75$ gel filtration. The protein concentration was $0.86 \mu \mathrm{g}$ per $\mathrm{ml}$. The oxidized and reduced form were prepared by treating with sodium ferricyanide and sodium dithionite, respectively.

the spectrum of the enzyme is clearly that of a heme protein, since there are a large Soret peak at $415 \mathrm{~nm}$ and two smaller peaks in the spectral region between 500 and $600 \mathrm{~nm}$. After treatment of the enzyme with potassium ferricyanide, the oxidized preparation displays peaks at 630,500 and $400 \mathrm{~nm}$. After treatment with sodium dithionite, the reduced preparation has peaks at 556 and $430 \mathrm{~nm}$. The spectra are very similar to those of hemoglobin ${ }^{10)}$. By comparing in more detail the spectral characteristics of the enzyme with those of hemoglobin prepared from blood of carp, it was found that this enzyme preparation contained a considerable amount of contaminating hemoglobin.

4. DEAE-Sephadex A-50 column chromatography The removal of hemoglobin from the enzyme preparation was carried out by chromatography on DEAE-Sephadex A-50. About $20 \mathrm{~m} l$ of the enzymatically active fractions was applied to a DEAE-Sephadex A-50 column $(1.5 \times 20 \mathrm{~cm})$ pre-equilibrated with $0.02 \mathrm{M}$ sodium phosphate buffer, $\mathrm{pH} 7.0$. As shown in Fig. 3, elution was performed by changing buffer concentration from 0.02 to $0.2 \mathrm{M}$, stepwisely. The first eluted larger peak, having an absorbance at $415 \mathrm{~nm}$, was found to contain a certain amount of hemoglobin by the spectroscopic analysis and 


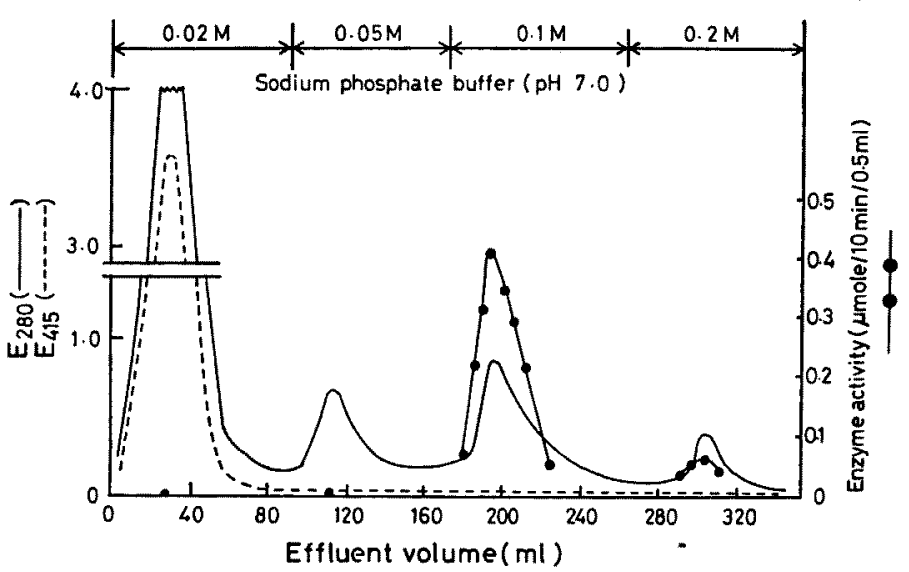

Fig. 3. Purification of DAsA-reductase from carp hepatopancreas by DEAE-Sephadex A-50 column chromatography. Column size: $1.5 \times 20 \mathrm{~cm}$, flow rate: $30 \mathrm{ml} / \mathrm{hr}$.

had no activity of DAsA-reductase. The enzyme activity was found in the fractions eluted with $0.1 \mathrm{M}$ buffer, and an absorbance at $415 \mathrm{~nm}$ was not observed in these fractions. Considering the results, it seems reasonable to conclude that the separation of hemoglobin from the enzyme preparation is almost complete.

Results of purification are summarized in Table 1. At the final step, the enzyme was

Table 1. Summary of purification of DAsA-reductase

\begin{tabular}{lccc}
\hline \multicolumn{1}{c}{ Fraction } & $\begin{array}{c}\text { Total } \\
\text { protein } \\
(\mathrm{mg})\end{array}$ & $\begin{array}{c}\text { Specific* } \\
\text { activity }\end{array}$ & $\begin{array}{c}\text { Yield } \\
(\%)\end{array}$ \\
\hline Homogenate & 3,432 & 0.028 & 100 \\
Supernatant & 1,672 & 0.051 & 87 \\
Ammonium sulfate fractionation & 440 & 0.158 & 71 \\
$\begin{array}{l}\text { Sephadex G-75 column } \\
\text { treatment }\end{array}$ & 155 & 0.271 & 44 \\
$\begin{array}{l}\text { DEAE-Sephadex A-50 column } \\
\text { treatment }\end{array}$ & 9 & 2.519 & 23 \\
\hline
\end{tabular}

* AsA formed ( $\mu \mathrm{moles}) / 10 \mathrm{~min} / \mathrm{mg}$ protein.

purified about 100 -fold with a yield of $23 \%$. It has been reported that DAsA-reductase was purified about 10 -fold in plant tissue $\left.{ }^{6}\right)$ and several-fold in animal tissue ${ }^{8}$. By comparing the degree of purification between these three preparations, DAsA-reductase here obtained from carp hepatopancreas is more homogeneous than the others.

\section{Properties of the purified enzyme}

1. Stability of the enzyme As shown in Fig. 4, the enzyme stored at $5^{\circ} \mathrm{C}$ for $40 \mathrm{hr}$ without bovine serum albumin lost $40 \%$ of its activity. Since the addition of bovine serum albumin prevented this loss, bovine serum albumin was added to the enzyme preparation 
prior to enzyme assay.

2. Time course and effect of enzyme concentration As given in Fig. 5, the reduction of DAsA by this enzyme proceeds linearly with time up to $20 \mathrm{~min}$. Figure 6 shows that the amount of AsA formed per $10 \mathrm{~min}$ increases in proportion to the protein concentration.
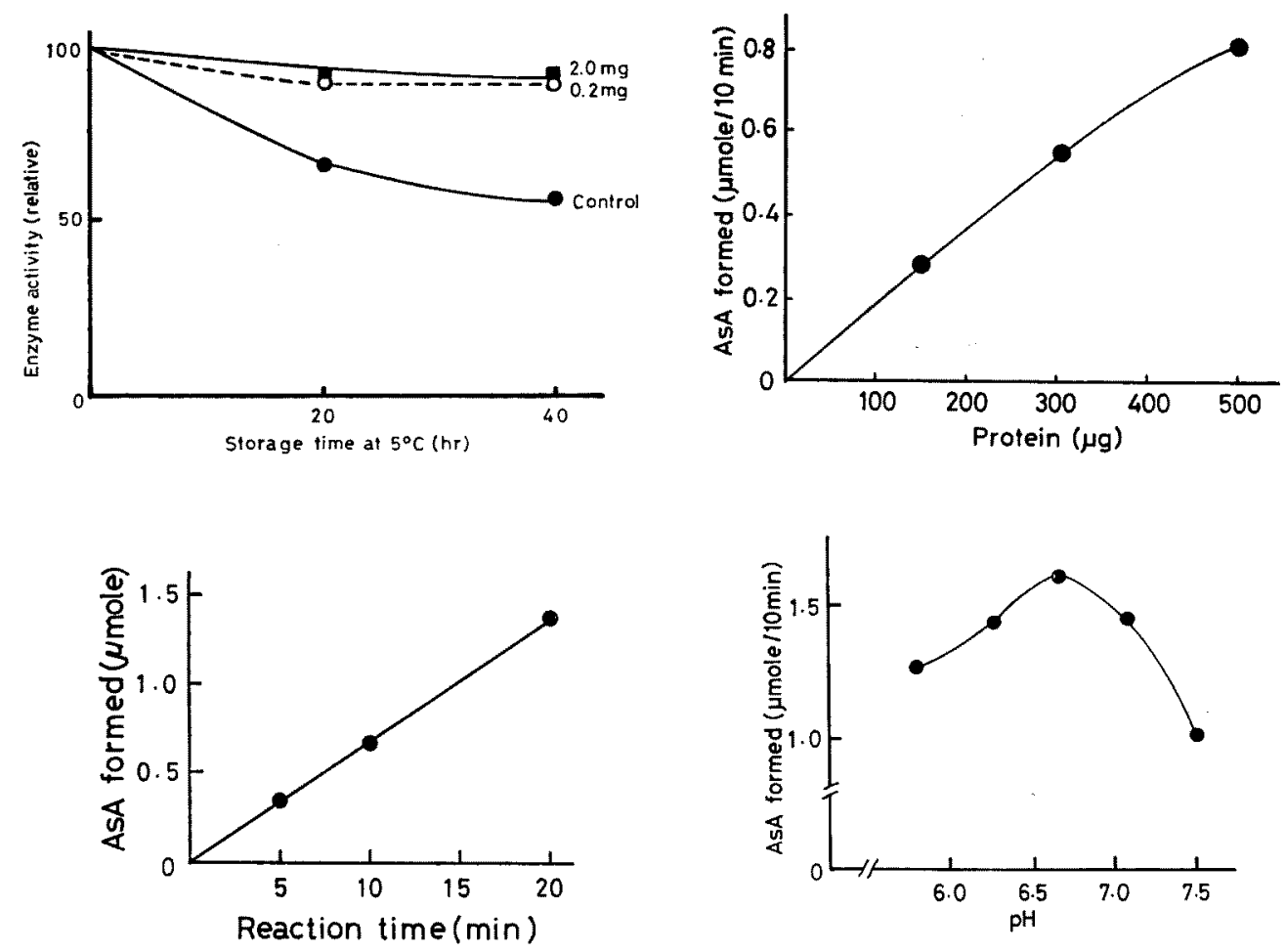

Fig. 4. Influence of added bovine serum albumin on the stability of DAsA-reductase. Bovine serum albumin $(2.0 \mathrm{mg}$ and $0.2 \mathrm{mg}$ ) were added to $1.0 \mathrm{ml}$ of the enzyme solution (protein conc. $0.32 \mathrm{mg} / \mathrm{ml}$ ) and the solutions were stored a $15^{\circ} \mathrm{C}$ for $20-40 \mathrm{hr}$; then the activities were assayed. Reaction mixture contained $0.32 \mathrm{mg}$ of the enzyme protein, $22.8 \mu \mathrm{moles}$ of GSH, $11.4 \mu$ moles of DAsA and $600 \mu$ moles of phosphate buffer, pH 6.3 , in a final volume of $6.0 \mathrm{ml}$. Incubation was carried out at $30^{\circ} \mathrm{C}$ by bubbling $\mathrm{N}_{2}$ gas through the mixture.

Fig. 5. Time course of DAsA reduction. Assay conditions were the same as in Fig. 4.

Fig. 6. Effect of enzyme concentration on DAsA-reductase activity. Assay conditions were the same as in Fig. 4.

Fig. 7. Effect of pH on DAsA-reductase activity. Assay conditions were the same as in Fig. 4, except for the indicated $\mathrm{pH}$.

3. Effect of $p H$ The $\mathrm{pH}$-activity curve of the enzyme is shown in Fig. 7. At $30^{\circ} \mathrm{C}$ for 10 min incubation, the optimum $\mathrm{pH}$ of the enzyme was near 6.7. This $\mathrm{pH}$ was slightly lower than the value reported for pea seeds ${ }^{6}$. In the $\mathrm{pH}$ range higher than 7.0, nonenzymatic reduction of DAsA by GSH was very rapid, so that exact activity measurements 
were not possible.

4. Effect of temperature The effect of incubation temperature on enzyme activity is shown in Fig. 8. The optimum temperature appears to be near $30^{\circ} \mathrm{C}$, under $5 \mathrm{~min}$

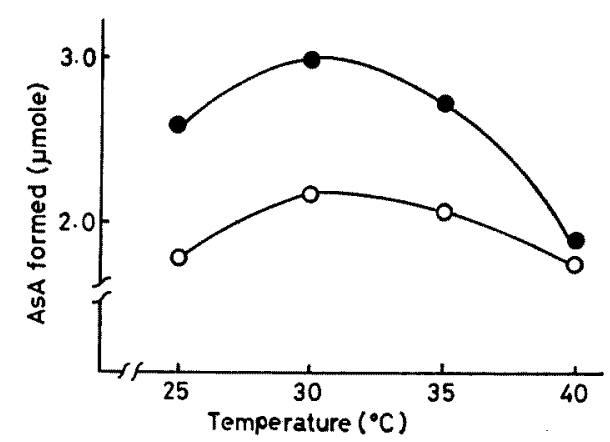

Fig. 8. Effect of temperature on DAsA-reductase activity. Assay conditions were the same as in Fig. 4, except for the indicated temprature. - $10 \mathrm{~min}$ incubation, -O-: $5 \mathrm{~min}$ incubation. or $10 \mathrm{~min}$ incubation. This temperature is somewhat lower than the value of $40^{\circ} \mathrm{C}$ reported for pea seeds ${ }^{6}$. HuGHes $^{(8)}$ reported that the enzyme preparation from rat liver lost only $50 \%$ of its activity after heating at $98^{\circ} \mathrm{C}$ for $6 \mathrm{~min}$. The lower optimum tem perature of the enzyme from carp may be due to its lability to heat.

5. Effect of metal ions The effect of some metal ions on enzyme activity is shown in Table 2. Enzyme activity was markedly inhibited by $\mathrm{Co}^{2+}$ and $\mathrm{Zn}^{2+}$ at $5 \times 10^{-3} \mathrm{M}$, by $\mathrm{Hg}^{+}$at $10^{-3} \mathrm{M}$ and com-

Table 2. Effect of metal ions on DAsA-reductase activity

\begin{tabular}{llc}
\hline Compound & $\begin{array}{c}\text { Concentration } \\
(\mathrm{M})\end{array}$ & $\begin{array}{c}\text { Relative } \\
\text { activity (\%) }\end{array}$ \\
\hline None & - & 100 \\
$\mathrm{CoCl}_{2}$ & $5 \times 10^{-3}$ & 35 \\
$\mathrm{Hg}_{2} \mathrm{Cl}_{2}$ & $1 \times 10^{-3}$ & 21 \\
$\mathrm{FeCl}_{2}$ & $1 \times 10^{-3}$ & 47 \\
$\mathrm{FeCl}_{3}$ & $5 \times 10^{-3}$ & N.D.* \\
$\mathrm{CuCl}_{2}$ & $5 \times 10^{-3}$ & 97 \\
$\mathrm{MgCl}_{2}$ & $5 \times 10^{-3}$ & 91 \\
$\mathrm{ZnCl}_{2}$ & $5 \times 10^{-3}$ & 12 \\
$\mathrm{MnCl}_{2}$ & $5 \times 10^{-3}$ & 91 \\
\hline
\end{tabular}

* Not detected.

pletely destroyed by $\mathrm{Fe}^{3+}$ at $10^{-3} \mathrm{M}$. On the other hand, the presence of $\mathrm{Cu}^{2+}, \mathrm{Mg}^{2+}$ and $\mathrm{Mn}^{2+}$ scarcely affect the activity at $5 \times 10^{-3} \mathrm{M}$, although YAMAGUCHI and JOSLYN ${ }^{6}$ have reported that $\mathrm{Cu}^{2+}$ brings about the greatest inhibition of the enzyme of pea seeds.

6. Effect of chemicals Some chemicals were added to the reductase system at a final concentration of $10^{-3}$ or $10^{-2} \mathrm{M}$. In the case of $\mathrm{CO}, \mathrm{CO}$ gas was passed through the enzyme solution for $5 \mathrm{~min}$ before enzyme assay. As shown in Table 3 , the metal chelating reagents, such as EDTA and $o$-phenanthrolic acid, and inhibitors to respiratory enzymes, such as sodium azide and sodium arsenate, scarcely affect the reaction rate under the experimental conditions. However, it was found that sodium cyanide at $10^{-2} \mathrm{M}$ and $\mathrm{CO}$ are effective inhibitors. Nucleotide mono-, di- and triphosphate slightly stimulated the enzyme activity. 
Table 3. Effect of chemicals on DAsA-reductase activity. The enzyme was treated with the chemicals for 5 min prior to addition of substrates.

\begin{tabular}{lcc}
\hline \multicolumn{1}{c}{ Reagent } & $\begin{array}{c}\text { Concentration } \\
(\mathrm{M})\end{array}$ & $\begin{array}{c}\text { Relative } \\
\text { activity }(\%)\end{array}$ \\
\hline None & $1 \times 10^{-2}$ & 100 \\
EDTA & $1 \times 10^{-3}$ & 139 \\
EDTA & $1 \times 10^{-2}$ & 115 \\
$o$-Phenanthrolic acid & $1 \times 10^{-2}$ & 91 \\
Sodium azide & $1 \times 10^{-8}$ & 96 \\
Sodium azide & $1 \times 10^{-2}$ & 107 \\
Sodium arsenate & $1 \times 10^{-8}$ & 111 \\
Sodium arsenate & $1 \times 10^{-2}$ & 87 \\
Sodium cyanide & $1 \times 10^{-3}$ & 7 \\
Sodium cyanide & $1 \times 10^{-2}$ & 83 \\
Carbon monoxide & $1 \times 10^{-3}$ & 46 \\
AMP & $1 \times 10^{-2}$ & 96 \\
AMP & $1 \times 10^{-8}$ & 122 \\
ADP & $1 \times 10^{-2}$ & 98 \\
ADP & $1 \times 10^{-3}$ & 117 \\
ATP & & 121 \\
ATP &
\end{tabular}

7. MICHAELIS constant Figure 9 and 10 show the relationship between the reaction velocity and the concentration of DAsA and GSH, respectively. The enzyme was saturated at about $1.0 \times 10^{-3} \mathrm{M}$ of DAsA and $2.0 \times 10^{-3} \mathrm{M}$ of GSH. The apparent MICHAELis constant $(\mathrm{km})$ was $5.7 \times 10^{-4} \mathrm{M}$ for DAsA and $1.5 \times 10^{-3} \mathrm{M}$ for GSH.

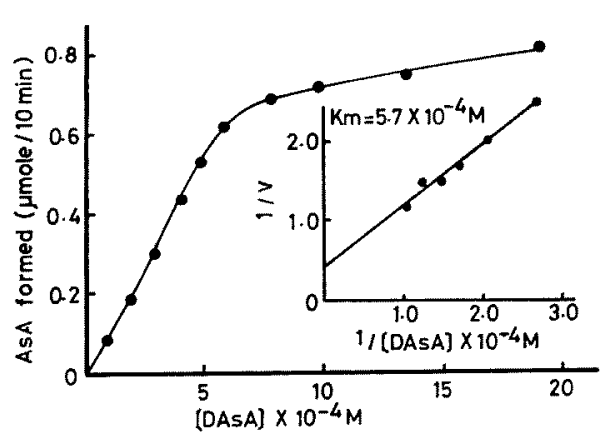

Fig. 9. Effect of DAsA concentration on DAsA-reductase activity. Assay conditions were the same as in Fig. 4.

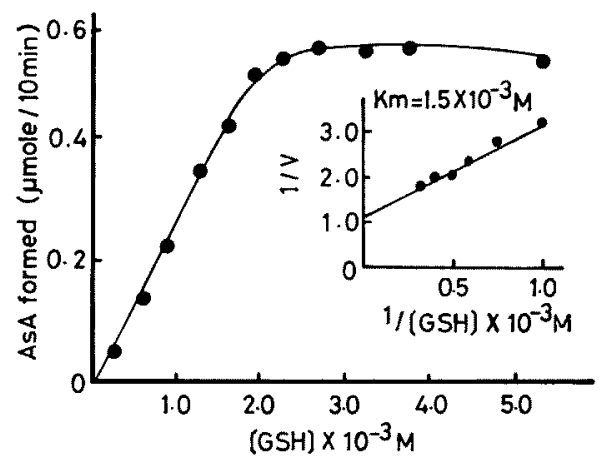

Fig. 10. Effect of GSH concentration on DAsA-reductase activity. Assay conditions were the same as in Fig. 4.

8. Substrate specificity The specificity of the enzyme with regard to hydrogen acceptor was examined. Dehydro-D-arabo ascorbic acid and dehydro-L-gluco ascorbic acid were prepared by oxidation of their reduced form with bromine. The comparison of these hydrogen acceptors is given in Table 4. Dehydro-D-arabo ascorbic acid, an optical isomer of DAsA, was able to accept hydrogen from GSH as effectively as DAsA, although dehydro-L-gluco ascorbic acid did so only to the extent of $30 \%$ of DAsA. As 
Table 4. Comparison of hydrogen acceptors. Assay conditions were the same as in Fig. 4, except for the indicated hydrogen acceptor.

\begin{tabular}{lc} 
Substrate & $\begin{array}{c}\text { Relative } \\
\text { activity }(\%)\end{array}$ \\
\hline Dehydro-L-ascorbic acid & 100 \\
Dehydro-D-arabo ascorbic acid & 111 \\
Dehydro-L-gluco ascorbic acid & 30 \\
\hline
\end{tabular}

Table 5. Comparison of hydrogen donors. Assay conditions were the same as in Fig. 4 , except for the indicated hydrogen donor.

\begin{tabular}{ll} 
Substrate & $\begin{array}{c}\text { Relative activity } \\
(\%)\end{array}$ \\
\hline GSH & 100 \\
L-Cysteine & N.D.* \\
Succinate & N.D. \\
iso-Citrate & N.D. \\
G-6-P & N.D. \\
NADH & N.D. \\
NADPH & N.D. \\
* Not detected. &
\end{tabular}

shown in Table 5, among the hydrogen donors tested, others than GSH are not able to transfer hydrogen to DAsA at all. These results indicate that the enzyme is specific for GSH as hydrogen donor.

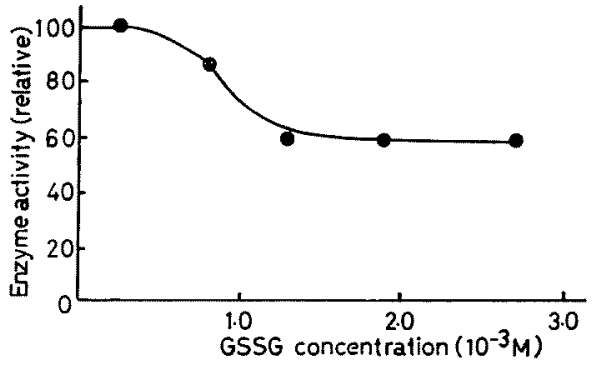

Fig. 11. Effect of GSSG on DAsA-reductase activity. Assay conditions were the same as in Fig. 4, except for the addition of GSSG.

9. Effect of reaction product As shown in Fig. 11, 40\% of enzyme activity is lost by the addition of oxidized glutathione (GSSG) above a concentration of $1.2 \times 10^{-3} \mathrm{M}$. On the other hand, inhibition was not observed by AsA up to a concentration of $2.0 \times 10^{-3} \mathrm{M}$.

The DAsA-reductase from carp hepatopancreas appears to be more specific for GSH as hydrogen donor than for DAsA as hydrogen acceptor. In addition, the enzyme was moderately inhibited by GSSG. Considering these results, DAsA-reductase system in vivo may be controlled with GSH. Unless some mechanism for the reconvertion of GSSG to GSH is available, it is considered that the reduction of DAsA may be insufficient owing to a lack of hydrogen donor and to product inhibition. As a result DAsA undergoes further change to products having no vitamin $\mathrm{C}$ activity. Therefore, the DAsA-reducing enzyme system may be regarded as an AsA-preserving mechanism in carp.

\section{References}

1) Y. Yamamoto, M. Sato, and S. Ikeda: This Bull., 43, 12-17 (1977).

2) J. E. CARTer and J. PACE: Nature, 201, 503 (1964).

3) S. IKeda: Mem. Resear. Inst. Food Sci., Kyoto Univ., 21, 26-35 (1960).

4) S. IKedA: Plant and Cell Physiol., 2, 291-299 (1961).

5) M. Yamaguch and M. A. Joslyn: Plant Physiol., 26, 757-772 (1951). 
6) M. YamaGuchi and M. A. Joslyn: Arch. Biochem. Biophys., 38, 451-465 (1952).

7) T. Kuninori and H. Matsumoto: Cereal Chem., 41, 39-46 (1964).

8) R. E. Hughes: Nature, 203, 1068-1069 (1964).

9) R. R. Grunert and R. H. Philltrs: Arch. Biochem., 30, 217-225 (1951).

10) F. MatsuUra and K. Hashimoto: This Bull., 21, 1158-1162 (1956). 